\title{
ICT dan Kinerja Organisasi : Peran Mediasi Inovasi
}

\author{
Nindira Sekarsari ${ }^{1}$ \\ Fakultas Ekonomi dan Bisnis Universitas Airlangga, Indonesia. \\ Email: nindirass@gmail.com
}

\begin{abstract}
ABSTRAK
Tujuan penelitian ini adalah untuk mengetahui bagaimana Information and Communication Technology dipengaruhi oleh inovasi yang menjadi variabel intervenig terhadap kinerja organisasi. Data dari penelitian ini diperoleh 70 kuesioner yang didistribusikan kepada karyawan pengguna sistem ERP yang bekerja di PT. Pembangunan Perumahan, Tbk yang merupakan salah satu perusahaan pengguna Enterprise Resoource Planning (ERP) di Indonesia. Variabel pengetahuan dan keterampilan berpengaruh terhadap kinerja organisasi, sedangkan sumber informasi dan infrastruktur tidak berpengaruh terhadap kinerja organisasi. Pengaruh inovasi dalam memediasi pengetahuan dan keterampilan serta sumber informasi terhadap kinerja perusahaan adalah partial mediasi karena nilai VAF berada pada rentang $>30-<70$. Selain itu inovasi dalam memediasi infrastruktur terhadap kinerja perusahaan adalah full mediasi karena nilai VAF berada pada rentang $>70$. Keterbatasan dalam penelitian ini adalah hanya menggunakan 1 perusahaan sebagai sample penelitian, sehingga kurang bisa menggeneralisasi hasil temuan ini.
\end{abstract}

Kata Kunci : $\quad$ ICT, Kinerja Organisasi, Inovasi.

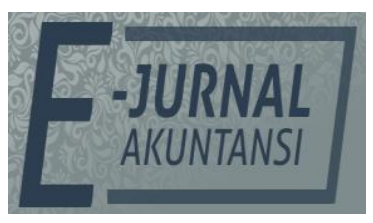

\section{ICT and Organization Performance: The Role of Innovation Mediation}

E-JA

e-Jurnal Akuntansi e-ISSN 2302-8556

Vol. 8 No. 2

Denpasar, Oktober

2019

Hal. 1948-1964

Artikel masuk: 19 Juli 2019

Tanggal diterima: 31 Agustus 2019

\section{ABSTRACT}

The purpose of this study was to find out how Information and Comunications Technology is influenced by innovations that become intervenig variable to organizational performance. Data from this study were obtained 70 questionnaires were distributed to employees of the Enterprise Resource Planning system users who work in PT. Housing Development, Tbk, which is one of the companies ERP users in Indonesia. Knowledge and skills variables affect the performance of the organization, while the source of information and infrastructure has no effect on organizational performance. The effect of innovation in mediating knowledge and skills and the source of information on company performance is partial mediation because the VAF values are in the range $>30-<70$. In addition, the innovation in mediating infrastructure for organizational performance is full mediation because the VAF values are in the range $>70$. Limitations of this research is to only use one company as research samples, making it less able to generalize the findings

Keywords: ICT, Organizational Performance, Innovation. 


\section{PENDAHULUAN}

Sistem informasi memiliki peranan yang begitu besar di dalam operasional manajemen organisasi untuk memperoleh efektivitas dan efisiensi serta keberhasilan strategi organisasi (Laudon \& Laudon, 2015). Sedangkan di era globalisasi informasi, penggunaan teknologi informasi dapat menciptakan keunggulan strategis organisasi, yaitu mendukung operasional organisasi, komunikasi kepada internal dan eksternal, melakukan pemantauan kegiatan kompetitor, pengambilan keputusan manajerial serta lingkungan yang cepat berubah membuat organisasi bisa berinovasi dan beradaptasi dengan cepat terhadap perubahan di lingkungan. Selain teknologi informasi yang berkembang harus dibarengi dengan keinginan organisasi secara proaktif memanfaatkan perkembangan ini dan upaya untuk menciptakan peluang bisnis baru. Kinerja organisasi merupakan sebuah alat ukur untuk menilai dan mengevaluasi berhasil atau tidak tujuan organisasi. Kinerja didefinisikan sebagai suatu gambaran tentang tingkatan maupun hasil pencapaian dari sebuah proses pelaksanaan baik kegiatan, program maupun kebijakan dalam rangka mewujudkan hal hal yang telah tertuang dalam perumusan skema strategis organisasi yaitu sasaran, tujuan, visi dan misi untuk membangun organisasi yang baik (Bastian, 2001). Tingkatan kinerja organisasi dapat dilihat dari sejauh mana organisasi mampu mencapai sasaran, tujuan, visi dan misi yang sudah ditetapkan. Pernyataan ini juga didukung oleh Mahsun, (2006) yang juga menyatakan definisi kinerja sebagai gambaran hasil atau tingkat pencapaian terhadap pelaksanaan suatu kegiatan, program dan kebijakan dalam mewujudkan serangkaian perencanaan yang tertuang dalam strategic planning suatu organisasi yaitu sasaran, tujuan, visi dan misi.

Dalam meningkatkan kinerjanya, setiap perusahaan harus menyusun strategi dengan matang dimana setiap perusahaan memiliki strategi yang berbeda dan strategi haruslah mampu menciptakan keunggulan kompetitif (Choy Chong et al., 2011). Dalam proses perumusan strategi perusahaan terdapat banyak hal yang mempengaruhi dan mendorong meningkatnya kinerja perusahaan diantaranya adalah memperoleh pengetahuan. Pengetahuan merupakan sumber kekuatan internal yang sulit diadaptasi oleh pesaing sehingga dapat dijadikan sebagai keunggulan kompetitif perusahaan. Selain itu pengetahuan berbeda dengan sumberdaya lainnya yang berkurang saat digunakan, justru pengetahuan akan meningkat saat digunakan dan akan semakin bernilai oleh organisasi (Aldi, 2005). Pengetahuan merupakan informasi yang terorganisasi sehingga dapat dimanfaatkan untuk pemecahan masalah dan mengambil keputusan, karena seseorang yang memiliki pengetahuan dan keterampilan akan meningkatkan inovasi dalam perusahaan sehingga kinerja perusahaan akan meningkat (Liebowitz, 1999).

Choy Chong et al. (2011) dalam penelitiannya tentang pengaruh sumber informasi berpengaruh terhadap kinerja organisasi menyatakan bahwa sumber informasi baik dari internal maupun eksternal perusahaan akan mempengaruhi besar kecilnya kinerja organisasi. Hal ini menunjukkan bahwa kinerja organisasi merupakan gambaran sumber informasi yang dimiliki oleh perusahaan baik dari internal maupun eksternal. Oleh karena itu, timbulah suatu kemungkinan yaitu sumber informasi akan mempengaruhi kinerja perusahaan. Dengan adanya 
inovasi akan memperkuat hubungan antara sumber informasi terhadap kinerja perusahaan. Sumber informasi yang didapatkan baik dari pihak internal maupun eksternal dapat menjadi inovasi baru bagi perusahaan untuk melakukan perubahan atau pembaharuan baru dalam rangka untuk meningkatkan kinerja perusahaan.

Technology Acceptance Model (TAM) merupakan salah satu model yang dibangun untuk memahami dan menganalisis faktor apa saja yang dapat mempengaruhi diterimanya penggunaan suatu teknologi komputer (Davis, 1989; Davis et al, 1989). TAM diadopsi dari model Theory of Reasoned Action (TRA) dengan dasar teori mengenai tindakan yang beralasan dari seseorang berupa reaksi, dan persepsi terhadap sesuatu dapat menentukan sikap dan perilaku dari orang tersebut.

Seperti reaksi dan persepsi dari pengguna Teknolgi Informasi (TI), dapat mempengaruhi sikap seseorang berkaitan dengan penerimaan sistem informasi tersebut. Salah satu faktor yang mempengaruhi adalah persepsi pengguna terhadap kemudahan penggunaan maupun manfaat yang dapat diperoleh dari TI tersebut. Hal ini dapat berpengaruh terhadap tindakan atau reaksi dari pengguna TI sebagai tolak ukur dari penerimaan teknologi yang diterapkan.

Model TAM dikembangkan dari teori psikologis yang menjelaskan mengenai perilaku pengguna komputer pada dasarnya dipengaruhi oleh kepercayaan (belief), keinginan (intention), sikap (attitude), dan hubungan perilaku pengguna (user behaviour relationship). Model TAM memiliki tujuan untuk menjelaskan faktor apa saja dari perilaku pengguna yang dapat mempengaruhi penerimaan teknologi.Dua variabel yang menggambarkan sikap pengguna terhadap penerimaan teknologi yaitu: kemudahan penggunaan (ease of use), dan kemanfaatan (usefulness)

Kemudahan dalam penggunaan dan kemanfaatan dapat dikaitkan dengan bagaimana respons pengguna dalam menggunakan TI seperti halnya dalam menggunakan sistem. Model ini menggambarkan bahwa penerimaan pengguna terhadap suatu sistem dipengaruhi oleh kemudahan penggunaan (ease of use) dan kemanfaatan (usefulness).

Pengetahuan teknologi dan keterampilan yang dimiliki karyawan atau pegawai merupakan faktor yang dapat mempengaruhi kinerja organisasi. Keterampilan adalah kemampuan seseorang menerapkan pengetahuan kedalam bentuk tindakan. Keterampilan seorang karyawan diperoleh melalui pendidikan dan latihan. Menurut Dessler (1997), pelatihan memberikan pegawai baru atau yang ada sekarang keterampilan yang mereka butuhkan untuk melaksanakan pekerjaan. Sirait (2006) menyebutkan terdapat beberapa manfaat yang diperoleh dengan adanya pendidikan dan latihan yakni: Membantu individu untuk dapat membuat keputusan dan pemecahan masalah secara lebih baik, internalisasi dan operasionalisasi, motivasi kerja, prestasi, tanggung jawab, dan kemajuan, mempertinggi rasa percaya diri dan pengembangan diri, membantu untuk mengurangi rasa takut dalam mengemban tugas-tugas baru.

Keterampilan adalah apa yang harus dimiliki seorang pegawai agar dapat melaksanakan tugas pekerjaannya. Serta merupakan kemampuan, kepandaian, reaktif, dan stamina kerja yang dimiliki individu untuk menyelesaikan pekerjaan.Pengetahuan teknologi informasi merupakan sebuah 
pengetahuan tentang bagaimana menggunakan atau memanfaatkan sebuah teknologi yang berfungsi sebagai penyedia dan pengakses informasi.

Brown \& Starkey (1994) memperkenalkan konsep kesadaran informasi yang akan dibuat dalam suatu organisasi. Konsep ini menyangkut sikap organisasi terhadap penilaian informasi sebagai sumber daya dan proses konsekuen dalam membuat pembelajaran / pengetahuan organisasi tersedia dengan memfasilitasi pengetahuantransfer dan berbagi di antara staff profesional. Peluang sumber informasi atau kemudahan memperoleh informasi sangat penting bagi para akuntan untuk memperbarui sumber informasi. Akses reguler atau jaringan komunikasi untuk informasi ahli atau sejauh mana informasi teknis dan profesional mudah tersedia dan dapat diakses oleh akuntan adalah contoh peluang sumber informasi.

Ketersediaan Infrastruktur Teknologi Informasi dan Komunikasi (TIK) Infrastruktur adalah segala struktur yang berwujud fisik yang digunakan untuk menopang keberjalanan kegiatan masyarakat dalam hal ini organisasi sehingga dapat menekan inefisiensi dari aktivitas organisasi (Grigg \& Darrel, 2000). Sedangkan teknologi informasi dan komunikasi (Information and communication technologies; ICT) adalah segala hal yang berkaitan dengan proses, penggunaan 25 sebagai alat bantu, manipulasi dan pengelolaan informasi serta segala sesuatu yang berkaitan dengan penggunaan alat bantu untuk memproses dan mentransfer data dari perangkat yang satu ke lainnya. Ketersediaan infrastruktur teknologi informasi dan komunikasi (TIK) di dalam lingkungan organisasi akan memiliki keunggulan dalam upaya meningkatkan penyediaan informasi terhadap proses pengambilan keputusan oleh manajemen dalam mengembangkan maupun penyusunan suatu sistem, sehingga senantiasa memiliki sinergi dalam peningkatan kinerja organisasi. Ketersediaan teknologi informasi dan komunikasi memiliki tiga fungsi penting dalam organisai, yaitu: Mengumpulkan dan menyimpan data tentang aktivitas-aktivitas dan transaksitransaksi yang dilaksanakan oleh organisasi, mengubah data menjadi informasi yang berguna bagi pihak manajemen untuk membuat keputusan dalam aktivitas perencanaan, pelaksanaan, dan pengawasan, dan enyediakan pengendalian yang memadai untuk menjaga harta organisasi.

Melalui fungsi tersebut TIK akan memudahkan pekerjaan karyawan melakukan otomatisasi terhadap suatu tugas atau proses yang menggantikan peran manusia dan dapat digunakan dalam membentuk strategi untuk menuju keunggulan yang kompetitif, serta memudahkan proses pengkomunikasian data, pembuatan laporan keuangan secara efisien dan efektif sehingga akan meningkatkan kinerja organisasi. 26 Jaringan komunikasi, surat elektronik, dan internet merupakan Teknologi yang telah dirancang oleh KM dalam mentransfer pengetahuan antar orang-orang dalam lingkungan organisasi melalui proses komunikasi. Komunikasi adalah suatu proses penyampaian informasi (pesan, ide, gagasan) dari satu pihak kepada pihak lain. Pada umumnya, komunikasi dilakukan secara lisan atau verbal yang dapat dimengerti oleh kedua belah pihak. Sedangkan teknologi komunikasi merupakan segala sesuatu yang berkaitan dengan penggunaan alat bantu untuk memproses dan mentransfer informasi dari satu pihak ke pihak lainnya. Melalui teknologi komunikasi, proses komunikasi yang dilakukan oleh orang-orang dalam lingkungan organisasi akan 
berjalan efektif dan efisien. Sehingga dalam mentransfer pengetahuan akan didukung oleh teknologi yang tersedia secara efektif. Keefektifan dalam komunikasi akan mempengaruhi kinerja organisasi, karena orang-orang didalamnya akan cepat menangkap informasi yang ingin disampaikan baik dari atasan maupun rekan kerjanya tanpa harus berhadapan langsung, karena didukung oleh tersedianya teknologi komunikasi (Eisenhardt \& Martin, 2000).

Untuk dapat menampilkan kinerja organisasi yang memuaskan atau tidak, diperlukan perubahan oganisasi yang bersifat strategis. Cara kerja organisasi yang masih menganut asas "seperti sedia kala" tidak lagi memadai di masa yang akan datang, di tengah persaingan yang bersifat lokal dan domestik bahkan regional dan global. Organisasi yang ingin meningkatkan produktivitas dan efektivitasnya, pada akhirnya menghadapi berbagai masalah yang timbul di masa depan, memerlukan cara berpikir dan bertindak yang inovatif. Inovasi dapat menyangkut penciptaan produk baru (baik dalam arti barang atau jasa), struktur baru, hubungan baru dan bahkan juga kultur baru.

Ciri-ciri utama organisasi masa depan, menurut Alfin Toffler, futuris yang terkenal itu, ialah fleksibilitas, kreativitas dan inovasi. Salah satu tugas dan fungsi manajerial yang makin mendesak dan penting di masa mendatang adalah mengelola perubahan strategis yang berkarakteristik diantaranya integrasi strategi organisasi dengan strukturnya, teknologi yang digunakan serta sumber daya manusia di dalamnya. Berbagai faktor tersebut disesuaikan lagi dengan tuntutan lingkungan eksternal organisasi. Maka menjadi penting kiranya dalam transformasi organisasi tersebut yaitu pemahaman yang utuh tentang transformasi organisasi, kultur organisasi, matriks "strategi-kultur" dan manajemen perubahan strategis. Pengelolaan empat isu perubahan (inovasi) organisasi tersebut berikut pengembangan dan pelaksanaannya yang bersifat partisipatif menjadi penting kiranya untuk dibahas.

Organisasi berinovasi merupakan tuntutan dari transformasi organisasi yang tidak lagi semata pengembangan organisasi manakala suatu organisasi belum mampu menampilkan performa yang memuaskan, atau tidak mampu menyesuaikan perubahan lingkungan eksternal yang demikian kompetitif, dan skala organisasi masih kecil dan bertumbuh pesat.

Analisis faktor-faktor yang Mempengaruhi Inovasi Produk untuk meningkatkan keunggulan mendefinisikan inovasi sebagai sebuah mekanisme perusahaan untuk beradaptasi dalam lingkungan yang dinamis, oleh karena itu perusahaan dituntut untuk mampu menciptakan pemikiran-pemikiran baru, gagasan-gagasan baru dan menawarkan produk yang inovatif serta peningkatan pelayanan yang memuaskan pelanggan (Kusumo, 2006).

Dalam sisi lain produk inovasi menurut Galbraith (1973) serta Schön \& Schön (1971) didefinisikan sebagai proses dari penggunaan teknologi baru ke dalam suatu produk sehingga produk tersebut mempunyai nilai tambah. Inovasi dapat dilakukan pada barang, pelayanan, atau gagasan-gagasan yang diterima oleh seseorang sebagai sesuatu yang baru, sehingga mungkin saja suatu gagasan telah muncul di masa lampau, tetapi dapat dianggap inovatif bagi konsumen yang baru mengetahuinya. Inovasi teknologi membantu perusahaan untuk membangun keunggulan kompetitif, layanan dan proses yang lebih efektif, bisnis yang baru, dan sebagainya. Hal ini merupakan kewajiban organisasi untuk 
memantau perubahan teknologi, melatih dan memotivasi karyawan untuk berinovasi karena teknologi meliputi semua aspek dari semua organisasi.

Schiemann (2011) menjelaskan inovasi sebagai mengembangkan dan melaksanakan ide-ide baru, kreatifitas yang mendorong ke arah jasa dan produk yang lebih baik, serta ketangkasan beradaptasi dengan lingkungan yang berubah atau lanskap yang kompetitif. Inovasi adalah bagian bentuk dari elemen terkompleks organisasi karena tidak tercakup dalam satu departemen karena inovasi dapat terjadi pada level organisasi, unit, proses, atau individu. Ragamnya definisi inovasi menyebabkan seringnya salah tafsir. Pengertian itu mengerucut pada makna "kreativitas" hingga "penciptaan sesuatu yang baru" dan ketangkasan organisasi pada tingkat terluas.

Keberadaan suatu organisasi pada hakikatnya untuk mencapai tujuan. Tujuan itu pada akhirnya harus dideskripsikan dengan jelas sehingga menjadi tolok ukur keberhasilan atau kegagalan dalam proses pencapaian tujuan itu. Untuk mengawal pencapaian tujuan terseut maka menjadi tugas pemimpin organisasi, yang diwujudkan dalam suatu manajemen kinerja. Sedangkan kinerja (performance) itu sendiri merupakan gambaran tingkat pencapaian pelaksanaan suatu kegiatan / program / kebijakan dalam rangka mewujudkan sasaran, tujuan, misi dan visi organisasi yang tertuang dalam strategic planning suatu organisasi. Sedangkan pengukuran kinerja (performance measurement) merupakan proses penilaian kemajuan pekerjaan terhadap tujuan dan sasaran yang telah ditentukan sebelumnya termasuk informasi atas : efisiensi penggunaan sumber daya dalam menghasilkan barang dan jasa, kualitas barang dan jasa (seberapa baik barang dan jasa terserahkan ke pelanggan dan sampai pelanggan terpuaskan); hasil kegiatan dibandingkan dengan maksud yang diinginkan dan efektifitas tindakan dalam mencapai tujuan (Mahsun, 2006) Sebuah organisasi yang memiliki budaya yang mempromosikan inovasi cenderung inovatif, yang pada gilirannya, kemungkinan akan menghasilkan pencapaian kinerja perusahaan yang unggul.

Model TAM menjelaskan sejauh mana seseorang percaya bahwa menggunakan suatu teknologi akan meningkatkan kinerja pekerjaannya. Pengetahuan teknologi dan keterampilan yang dimiliki karyawan atau pegawai merupakan faktor yang dapat mempengaruhi kinerja organisasi. Pengetahuan teknologi informasi merupakan sebuah pengetahuan tentang bagaimana menggunakan atau memanfaatkan sebuah teknologi yang berfungsi sebagai penyedia dan pengakses informasi (Dessler, 1997). Menurut Dessler (1997), pelatihan memberikan pegawai baru atau yang ada sekarang keterampilan yang mereka butuhkan untuk melaksanakan pekerjaan. Pengetahuan teknologi informasi merupakan salah satu faktor penunjang dalam peningkatan kinerja(Sirait, 2006). Dalam pengoperasiannya dibutuhkan pengetahuan dasar tentang cara menggunakan komputer serta mengakses internet. Keterampilan dan pengetahuan teknologi yang dimiliki karyawan akan dipraktekkan dalam melaksanakan tugas-tugasnya. Setiap perusahaan membutuhkan karyawan yang memiliki keterampilan dan pengetahuan yang baik yang dapat meningkatkan performa perusahaan, karyawan yang memiliki pengetahuan dan keterampilan akan lebih efisien dalam menyelesaikan pekerjaannya, sehingga hal ini akan memberikan pengaruh terhadap kinerja organisasi. 
$\mathrm{H}_{1}$ :Pengetahuan dan keterampilan berpengaruh terhadap kinerja organisasi.

Model TAM memberikan pandangan mengenai kemudahan pengguna konstruk ini memengaruhi konstruk kegunaan, sikap, intensi, dan penggunaan teknologi sesungguhnya. Brown \& Starkey (1994) memperkenalkan konsep kesadaran informasi yang akan dibuat dalam suatu organisasi. Peluang sumber informasi atau kemudahan memperoleh informasi sangat penting bagi para akuntan untuk memperbarui sumber informasi. Akses reguler atau jaringan komunikasi untuk informasi ahli atau sejauh mana informasi teknis dan profesional mudah tersedia dan dapat diakses oleh akuntan adalah contoh peluang sumber informasi (Gebauer \& Schober, 2006). Dengan adanya sumber informasi baik dari pihak internal maupun eksternal maka akan dapat meningkatkan kinerja organisasi. Semakin sumber informasi dapat dipercaya dan mudah untuk diakses oleh perusahaan akan memberikan kemudahan bagi individu dalam perusahaan sehingga tidak terjadi kesalahan dalam penggunaannya. Sumber informasi di dalam organisasi mengalir secara vertikal dan horizontal, informasi dapat digunakan untuk meningkakan efektifitas dan efisiensi operasional, apabila informasi yang didapatkan baik maka kinerja organisasi dalam perusahaan tersebut juga akan semakin meningkat, begitu pula sebaliknya.

$\mathrm{H}_{2}$ : Sumber informasi berpengaruh terhadap kinerja organisasi.

Model TAM menjelaskan bahwa sejauh mana orang percaya bahwa menggunakan suatu teknologi. Infrastruktur adalah segala struktur yang berwujud fisik yang digunakan untuk menopang keberjalanan kegiatan masyarakat dalam hal ini organisasi sehingga dapat menekan inefisiensi dari aktivitas organisasi (Grigg, 2000). Teknologi adalah salah satu aspek yang paling penting dalam memfasilitasi atau sebagai sarana implementasi KM yang efektif (Eisenhardt \& Martin, 2000). Saat ini banyak perusahaan yang melengkapi kebutuhan organisasinya dengan infrastruktur teknologi informasi dan komunikasi (TIK). Dengan adanya teknologi akan memudahkan pekerjaan karyawan melakukan otomatisasi terhadap suatu tugas atau proses yang menggantikan peran manusia dan dapat digunakan dalam membentuk strategi untuk menuju keunggulan kompetitif. Ketersediaan infrastruktur teknologi informasi dan komunikasi (TIK) di dalam lingkungan organisasi akan memiliki keunggulan dalam upaya meningkatkan penyediaan informasi terhadap proses pengambilan keputusan oleh manajemen dalam mengembangkan maupun penyusunan suatu sistem, sehingga senantiasa memiliki sinergi dalam peningkatan kinerja organisasi. Rumusan hipotesis antara ketersediaan infrastruktur teknologi informasi dan komunikasi dengan kinerja organisasi.

$\mathrm{H}_{3}$ : Infrastruktur berpengaruh terhadap kinerja organisasi.

Menurut model TAM merupakan salah satu teori tentang penggunaan sistem teknologi informasi yang dianggap sangat berpengaruh dan umumnya digunakan untuk menjelaskan penerimaan individual terhadap penggunaan sistem teknologi informasi. Perilaku organisasi mengkaji dampak perorangan, kelompok dan struktur pada perilaku dalam organisasi dengan maksud menerapkan pengetahuan untuk memperbaiki keefektifan organisasi. Terdapat hubungan antara inovasi dengan kinerja organisasi. Pada inovasi produk, proses inovasi produk akan berdampak secara langsung terhadap keberhasilan 
perusahaan yang ditunjukkan dengan peningkatan revenue maupun profitnya (Ellitan \& Anatan, 2009). Dalam hal inovasi proses, Reengineering (inovasi proses) yang berhasil akan meningkatkan kinerja organisasi dan kinerja karyawan. Perubahan proses bisnis akan mendatangkan hasil kinerja yang dapat diukur dengan market share dan atau profitabilitas (Ellitan \& Anatan, 2009). Dalam hal inovasi teknologi, kemajuan teknologi akan memainkan peran penting dalam mencapai kemampuan jangka panjang (Stacey \& Ashton, 1990). Tipe inovasi proses merupakan bentuk inovasi yang menekankan pada metodemetode baru dalam pengoperasiaan dengan cara membuat teknologi baru atau mengembangkan teknologi yang sudah ada. Semakin perusahaan tersebut dapat terus berinovasi dalam produknya maka juga akan meningkatkan kinerja organisasi.

$\mathrm{H}_{4}$ : Inovasi berpengaruh terhadap kinerja organisasi.

Pengetahuan dan keterampilan diakui sebagai elemen penting infrastruktur TI (Byrd \& Turner, 2000). Infrastruktur IT harus memungkinkan perubaha untuk secara efektif menanggapi kondisi pasar baru. Infrastruktur IT manusia mengacu pada keterampilan manusia dan organisasi, pengetahuan.

Hasil penelitian Han et al., (1998) yang menyimpulkan bahwa hubungan inovasi dan kinerja tidak hanya menekankan pemisahan kontribusi inovasi administratif dan teknis terhadap kinerja perusahaan tetapi juga mendukung sinergi antara 2 jenis inovasi tersebut untuk meningkatkan kinerja perusahaan secara keseluruhan. Rachman (2014) dalam penelitiannya di industri perhotelan menemukan bahwa inovasi berpengaruh positif signifikan terhadap kinerja bisnis. Semakin individu dalam perusahaan memiliki pengetahuan dan keterampilan yang memadai akan terus meningkatkan kemampuan mereka untuk menciptakan inovai yang akan mendorong kinerja organisasi sehingga lebih optimal.

$\mathrm{H}_{5}$ : Pengetahuan dan keterampilan berpengaruh terhadap kinerja organisasi dengan inovasi sebagai mediasi.

Sesuai dengan model TAM, organisasi berusaha untuk dapat menyesuaikan diri dengan perubahan inovasi dalam lingkungan bisnis yang ada. Di era modern seperti saat ini, teeknologi selalu berkembang sehingga inovasi diperlukan dalam suatu perusahaan. Inovasi merupakan kekuatan penting dalam peningkatan kinerja organisasi serta dapat meningkatkan pertumbuhan ekonomi dan pembangunan (Agbim et al., 2013). Perusahaan yang memiliki infrastruktur yang baik adalah perusahaan yang dapat meningkatkan kinerja nya sehingga dapat menghasilkan profitabilitas bagi perusahaan, hal ini dapat dilakukan dengan adanya inovasi di dalam perusahaan tersebut. Dengan adanya infrastruktur yang baik akan dapat memfasilitasi penyediaan tenaga ahli yang handal dan dapat dipercaya. Dengan adanya hal tersebut perusahaan akan dapat mencapai tujuan yang diinginkan. Kualitas pelayanan yang baik dengan didukung adanya infrastruktur yang baik maka akan dapat meningkatkan kinerja organisasi. Untuk meningkatkan infrastruktur dibutuhkan adanya strategi inovasi yang diterapkan secara berkelanjutan, yang digunakan untuk keberlanjutan perusahaannya. Adanya inovasi menentukan kesuksesan entitas (Bontis et al.,2002). Dengan adanya inovasi yang baik dan didorong dengan 
infrastruktur yang memadai dari perusahaan maka kinerja organisasi akan semakin baik dan meningkat.

$\mathrm{H}_{6}$ : Infrastruktur berpengaruh terhadap kinerja organisasi dengan inovasi sebagai mediasi.

Hubungan antara sumber informasi dan inovasi, serta hubungan antara inovasi kinerja organisasi dikembangkan berdasarkan teori RBV. Dalam teori RBV dikatakan bahwa pengetahuan adalah aset utama selain dari yang tangible dalam suatu organisasi. Keberhasilan suatu organisasi tergantung pada menajemen pengetahuan dalam menghadapi perubahan lingkungan. Kemampuan beradaptasi dengan perubahan lingkungan akan meningkatkan inovasi dan kinerja organisasi. Peningkatan kinerja perusahaan tidak lepas dari adanya sumber informasi baik sumber informasi secara internal maupun eksternal. Kedua sumber tersebut dapat meningkatkan kinerja perusahaan. Suatu perusahaan yang memiliki inovasi yang tinggi tidak akan mudah terpengaruh dari informasi yang buruk. Perusahaan yang memiliki sumber informasi yang baik adalah perusahaan yang dapat mengakses data-data yang dibutuhkan kapanpun diinginkan serta didokumentasikan secara benar. Dengan memanfaatkan inovasi yang dimiliki maka perusahaan tersebut dapat membuat cara agar hal itu dapat mudah diakses sehingga data apapun yang dibuthkan akan mudah untuk diperoleh. Hal ini lah yang akan meningkatkan kinerja perusahaan.

$\mathrm{H}_{7}$ : Sumber informasi berpengaruh terhadap kinerja organisasi dengan inovasi sebagai mediasi.

Tujuan penelitian ini adalah untuk mengetahui bagaimana ICT (Pengetahuan ICT dan keterampilan, infastruktur, dan sumber informasi) terhadap kinerja perusahaan. Lebih lanjut, yang menjadi pusat perhatian dari penelitian ini ada pada peran mediasi dari hubungan antara ICT dengan kinerja perusahaan. Pencapaian tujuan perusahaan tidak lepas dari hal-hal yang perlu diperhatikan. Kinerja yang baik perlu didukung dengan infrastruktur (sarana dan prasarana), sumber informasi, dan pengetahuan serta keterampilan dari setiap orang dalam perusahaan tersebut. Namun, dengan dorongan inovasi akan lebih meningkatkan kinerja perusahaan.

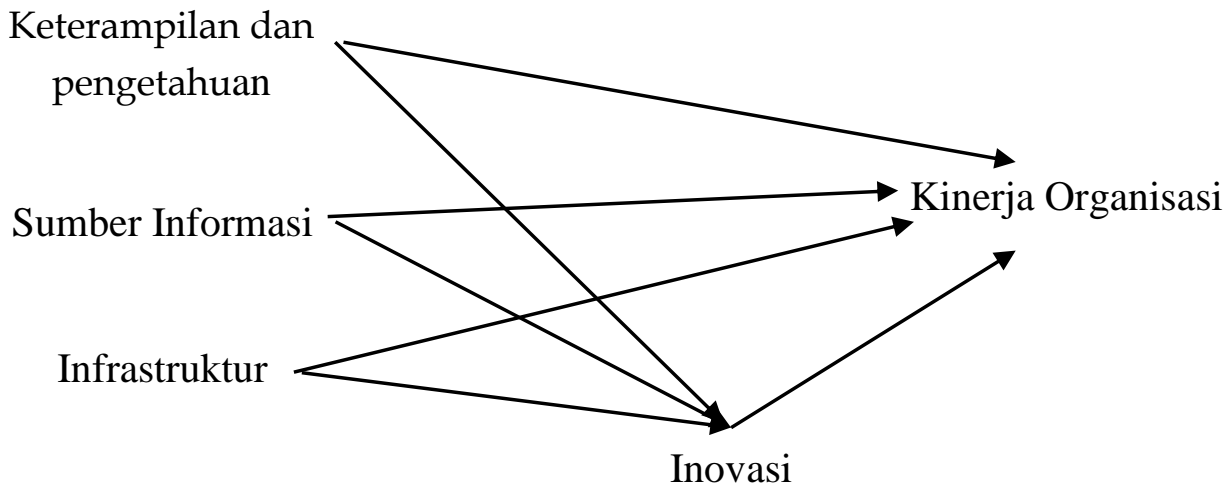

Gambar 1. Model Penelitian

Sumber: Data Penelitian, 2019 


\section{METODE PENELITIAN}

Metode analisis data dalam penelitian ini menggunakan analisis deskriptif dan analisis statistik inferensial. Analisis statistik inferensial yang digunakan adalah Structural Equation Model (SEM) dengan pendekatan Partial Least Square (PLS). Penelitian dilakukan mulai bulan April 2019 hingga Mei 2019. Perusahaan yang dipilih sebagai lokasi penelitian adalah perusahaan BUMN PT Pembangunan Perumahan melalui kuisioner yang didistribusikan kepada karyawan pengguna teknologi. Prosedur penentuan sampel dilakukan secara convenience sampling, merupakan teknik penentuan sampel yang dilakukan secara tidak acak, tetapi menunjuk perusahaan yang diperkirakan dapat memberikan informasi terkait penelitian ini. Jumlah subjek penelitian ini adalah sebanyak 70 responden diperoleh untuk penelitian ini.

Variabel Independen dalam penelitian ini adalah: Yang pertama, keterampilan dan pengetahuan yaitu sebuah pengetahuan tentang bagaimana menggunakan atau memanfaatkan sebuah teknologi yang berfungsi sebagai penyedia dan pengakses informasi. Yang kedua, sumber informasi yaitu adalah segala sesuatu yang menjadi perantara dalam menyampaikan informasi, media informasi untuk komunikasi massa. Yang ketiga, Infrastruktur segala struktur yang berwujud fisik yang digunakan untuk menopang keberjalanan kegiatan masyarakat dalam hal ini organisasi sehingga dapat menekan inefisiensi dari aktivitas organisasi. Ketiga variabel independen diukur dengan kuesioner yang dikembangkan oleh (Davenport, 1998; Syed-Ikhsan \& Rowland, 2004; Stankosky, 2005; Woodward et al., 1996). Instrumen meminta individu untuk menunjukkan kesepakatan atau ketidaksetujuan mereka dengan 10 pertanyaan. Pilihan tanggapan berkisar dari (1) sangat tidak setuju hingga (5) sangat setuju.

Variabel Moderasi. Variabel mediasi dalam penelitian ini adalah inovasi yaitu suatu proses dan hasil pengembangan pemanfaatan suatu produk atau sumber daya yang telah ada sebelumnya, sehingga memiliki nilai yang lebih berarti. Variabel moderasi diukur dengan menggunakan kuesioner.Pertanyaan mengenai variabel moderasi ini ada pada bagian pertama dan kedua dari kuesioner.Keahlian pengguna diukur dengan kuesioner yang dikembangkan oleh. Melalui 15 pertanyaan pada bagian satu dan 4 pertanyaan ada bagian dua dari kuesioner meminta individu untuk menunjukkan kesepakatan atau ketidaksetujuan mereka mengenai apakah perusahaan sudah melakukan inovasi yang sudah dimiliki manfaatnya untuk respoden.Pilihan tanggapan berkisar dari (1) sangat tidak setuju hingga (5) sangat setuju.

Variabel Dependen. Variabel dependen dalam penelitian ini adalah kinerja organisasi yaitu merupakan indikator tingkatan prestasi yang dapat dicapai dan mencerminkan keberhasilan suatu organisasi, serta merupakan hasil yang dicapai dari perilaku anggota organisasi. Kinerja organisasi diukur dengan kuesioner yang dikembangkan oleh oleh (Davenport, 1998; Syed-Ikhsan \& Rowland, 2004; Stankosky, 2005; Woodward et al., 1996). Pertanyaan dalam kuesioner meminta individu untuk menunjukkan kesepakatan atau 
ketidaksetujuan mereka dengan 5 pertanyaan yang mencerminkan mengenai kinerja organisasi.Pilihan tanggapan berkisar dari (1) sangat tidak setuju hingga (5) sangat setuju.

\section{HASIL DAN PEMBAHASAN}

Sedangkan Tabel 1 merupakan hasil analisis faktor dan koefisien reliabilitas. Pengujian reliabilitas variabel menggunakan teknik composite reliability. Untuk melihat reliabel atau tidaknya suatu alat ukur dilakukan melalui koefisien reliabilitas dengan nilai koefisien reliabilitas harus lebih besar dari 0,7.

Tabel 1. Analisis Data

\begin{tabular}{lrr}
\hline & $\mathrm{N}$ & $\%$ \\
\hline Posisi & 40 & 57,14 \\
Staff & 5 & 7,14 \\
Asisten Manager & 25 & 35,71 \\
Manager & & \\
Lama Bekerja & 4 & 5,71 \\
$<1$ thn & 29 & 41,42 \\
1-5 thn & 18 & 25,71 \\
$5-10$ thn & 18 & 25,71 \\
$>10$ thn & & \\
Jenis Kelamin & 56 & 80 \\
Laki-Laki & 14 & 20 \\
Perempuan & & \\
Pendidikan Terakhir & 11 & 15,71 \\
SMA & 4 & 5,71 \\
D1/D2/D3/D4 & & 75,71 \\
& 53 & \\
S1 & 2 & 2,85 \\
S2 & 0 & 0,00 \\
Other & &
\end{tabular}

Sumber : Data Penelitian, 2019

Selain itu dalam Tabel ini juga disajikan bahwa seluruh proksi memiliki nilai outer loading factor lebih besar dari 0,5. Hal ini dapat disimpulkan bahwa seluruh indikator sudah layak untuk dijadikan indikator yang dapat merefleksikan masing-masing variabel yang bersesuaian.

Pengukuran discriminant validity adalah dengan membandingkan nilai square root Average Variance Extracted (AVE) setiap konstruk dengan korelasi antara konstruk lainnya dalam model. Direkomendasikan nilai AVE harus lebih besar dari 0,5. Dalam Tabel 2 menunjukkan nilai AVE dari masing masing variabel lebih besar dari 0,5, sehingga dapat disimpulkan bahwa variabel yang digunakan sudah valid dan dapat dipercaya.

Hipotesis yang telah diajukan akan diuji dengan menggunakan model Structural Equation Model (SEM) dengan model analisis Partial Least Square (PLS). Analisis PLS diuji dengan menggunakan bantuan software WarpPLS 5.0 for windows untuk meneliti pengaruh antara pengetahuan dan keterampilan, sumber informasi, dan infrastruktur terhadap kinerja organisasi dan untuk 
meneliti pengaruh inovasi sebagai variabel mediasi antara Information and Communications Technology terhadap kinerja organisasi.

Tabel 2. Hasil Outer Loading, Reliability, AVE

\begin{tabular}{|c|c|c|c|c|c|}
\hline & & $\begin{array}{l}\text { Outer } \\
\text { Loading }\end{array}$ & Reliability & AVE & Kesimpulan \\
\hline PIC 1 & $\begin{array}{l}\text { Semua karyawan diberikan } \\
\text { pelatihan yang memadai secara } \\
\text { internal untuk menggunakan } \\
\text { komputer pada perusahaan }\end{array}$ & 0,921 & & & Signifikan \\
\hline PIC 2 & $\begin{array}{l}\text { Semua karyawan diberikan } \\
\text { pelatihan yang memadai secara } \\
\text { internal untuk menggunakan } \\
\text { alat ICT (perangkat lunak) pada } \\
\text { perusahaan }\end{array}$ & 0,925 & 0,924 & 0,801 & Signifikan \\
\hline PIC3 & $\begin{array}{l}\text { Pengetahuan teknologi } \\
\text { informasi dan komunikasi pada } \\
\text { perusahaan mudah untuk } \\
\text { dibagikan }\end{array}$ & 0,837 & & & Signifikan \\
\hline IFT1 & $\begin{array}{l}\text { Perusahaan memiliki } \\
\text { infrastruktur ICT terbaru yang } \\
\text { dapat membantu penciptaan } \\
\text { dan berbagi pengetahuan }\end{array}$ & 0,932 & & & Signifikan \\
\hline IFT2 & $\begin{array}{l}\text { ICT dapat menaikkan atau } \\
\text { mempercepat dalam } \\
\text { penyelesaian pekerjaan untuk } \\
\text { mencari informasi }\end{array}$ & 0,202 & & & Signifikan \\
\hline IFT 3 & $\begin{array}{l}\text { ICT memfasilitasi karyawan } \\
\text { dalam melakukan pekerjaan } \\
\text { sehari-hari }\end{array}$ & 0,917 & 0,771 & 0,584 & Signifikan \\
\hline SI 1 & $\begin{array}{l}\text { Pengetahuan/Informasi yang } \\
\text { dibuat dan disimpan dalam } \\
\text { dokumentasi kertas dapat } \\
\text { dengan mudah diakses, } \\
\text { dibagikan, dan ditransfer }\end{array}$ & 0,843 & & & Signifikan \\
\hline SI 2 & $\begin{array}{l}\text { Pengetahuan/Informasi yang } \\
\text { dibuat dan disimpan dalam } \\
\text { dokumentasi elektronik dapat } \\
\text { dengan mudah diakses, } \\
\text { dibagikan, dan ditransfer }\end{array}$ & 0,940 & & & Signifikan \\
\hline SI 3 & $\begin{array}{l}\text { Pengetahuan / Informasi dari } \\
\text { individu dapat dibagi dan } \\
\text { ditransfer melalui diskusi / } \\
\text { pertemuan formal tanpa } \\
\text { adanya kesulitan }\end{array}$ & 0,906 & & & Signifikan \\
\hline SI 4 & $\begin{array}{l}\text { Pengetahuan / Informasi dari } \\
\text { individu dapat dibagi dan } \\
\text { ditransfer melalui diskusi / } \\
\text { pertemuan informal tanpa } \\
\text { kesulitan } \\
\text { Bersambung ... }\end{array}$ & 0,898 & 0,943 & 0,806 & Signifikan \\
\hline
\end{tabular}


Lanjutan Tabel 2.

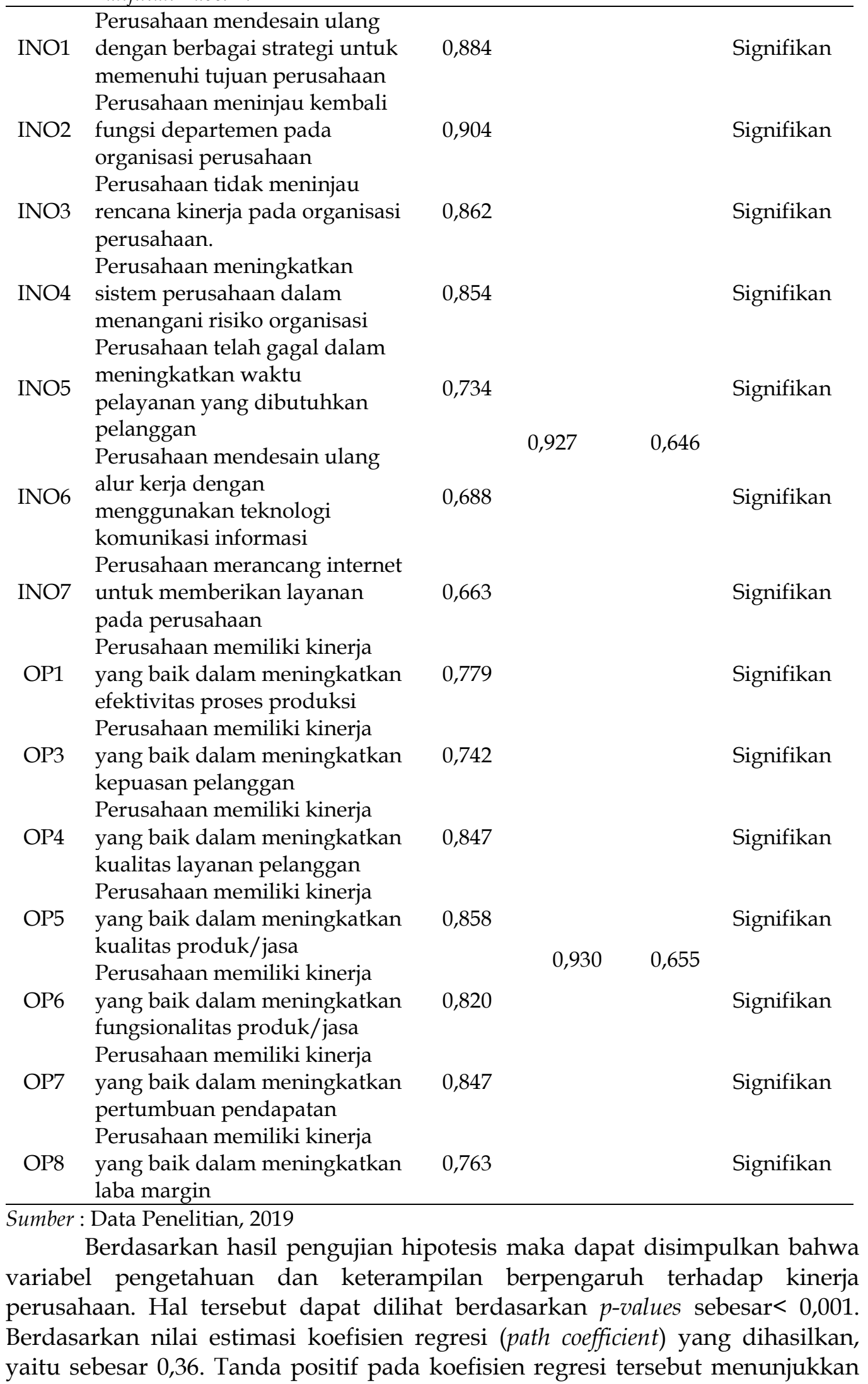


hubungan yang searah antara pengetahuan dan keterampilan dengan kinerja perusahaan, dimana jika pengetahuan dan keterampilan meningkat satu kali, maka kinerja organisasi akan mengalami peningkatan sebesar 0,36 kali. Dapat disimpulkan bahwa hipotesis 1 (satu) bahwa variabel pengetahuan dan keterampilan berpengaruh terhadap kinerja perusahaan. Hasil penelitian ini sejalan dengan penelitian yang dilakukan oleh Dessler (1997). Pengetahuan teknologi dan keterampilan yang dimiliki karyawan atau pegawai merupakan faktor yang dapat mempengaruhi kinerja organisasi. Hasil pengujian hipotesis dapat dilihat pada Tabel 3.

Tabel 3. Pengujian Hipotesis

\begin{tabular}{lll}
\hline \multicolumn{2}{l}{ Hasil Uji Pengaruh Langsung } & \\
\hline & \multicolumn{1}{l}{ Path Coefficient } & P-Value \\
PIC $\longrightarrow$ OP & 0,36 & $<0,001$ \\
IFT $\longrightarrow$ OP & $-0,058$ & 0,31 \\
SI $\longrightarrow$ P & 0,111 & 0,166 \\
INO $\longrightarrow$ OP & 0,172 & 0,06 \\
Hasil Uji Pengaruh Tidak Langsung (Sobel Test) & \\
Path & Path Coefficient & VAF \\
PIC- $\rightarrow$ INO- $\rightarrow$ OP & 0,29137 & $44,731 \%$ \\
SI- $\rightarrow$ INO- $\rightarrow$ OP & 0,238422 & $68,233 \%$ \\
IFT- $\rightarrow$ INO- $\rightarrow$ OP & 0,289728 & $83,320 \%$ \\
\hline
\end{tabular}

Sumber : Data Penelitian, 2019

Variabel sumber informasi tidak berpengaruh terhadap kinerja perusahaan. Hal tersebut dapat dilihat berdasarkan p-values sebesar 0,166. Berdasarkan nilai estimasi koefisien regresi (path coefficient) yang dihasilkan, yaitu sebesar 0,111.Dapat disimpulkan bahwa hipotesis 2 (dua) bahwa variabel sumber informasi tidak berpengaruh terhadap kinerja perusahaan. Hal ini sejalan dengan penelitian yang dilakukan oleh Dessler (1997) yang menyatakan bahwa sumber informasi bukanlah hal yang utama yang mempengaruhi kinerja organisasi. Sumber informasi tidak berpengaruh karena pengetahuan sebagai sumber daya penggerak organisasi, sehingga menjadi organisasi yang kompetitif dan berdaya saing.

Variabel infastruktur tidak berpengaruh terhadap kinerja perusahaan.Hal tersebut dapat dilihat berdasarkan p-values sebesar 0,31. Berdasarkan nilai estimasi koefisien regresi (path coefficient) yang dihasilkan, yaitu sebesar -0,058. Dapat disimpulkan bahwa hipotesis 3 (tiga) bahwa variabel infrastruktur tidak berpengaruh terhadap kinerja perusahaan. Hasil penelitian ini mendukung hasil penelitian Oktari \& Nasir (2011) yang menyatakan bahwa pemanfaatan infrastruktur tidak berpengaruh terhadap kinerja organisasi.

Variabel inovasi berpengaruh terhadap kinerja organisasi. Hal tersebut dapat dilihat berdasarkan p-values sebesar 0,06. Berdasarkan nilai estimasi koefisien regresi (path coefficient) yang dihasilkan, yaitu sebesar 0,172.Dapat disimpulkan bahwa hipotesis 4 (empat) bahwa variabel inovasi berpengaruh terhadap kinerja perusahaan. Hasil penelitian ini sejalan dengan penelitian yang dilakukan oleh (Stacey \& Ashton, 1990). Perilaku organisasi mengkaji dampak perorangan, kelompok dan struktur pada perilaku dalam organisasi dengan maksud menerapkan pengetahuan untuk memperbaiki keefektifan organisasi. 
Pengaruh inovasi dalam memediasi pengetahuan dan keterampilan serta sumber informasi terhadap kinerja organisasi adalah partial mediasi karena nilai VAF berada pada rentang $20 \%-70 \%$.

\section{SIMPULAN}

Secara umum penelitian ini bermaksud untuk mengetahui bagaimana ICT (Pengetahuan ICT dan keterampilan, infastruktur, dan sumber informasi) terhadap kinerja perusahaan. Lebih lanjut, yang menjadi pusat perhatian dari penelitian ini ada pada peran mediasi dari hubungan antara Information and Communications Technology dengan kinerja perusahaan.Pencapaian tujuan perusahaan tidak lepas dari hal-hal yang perlu diperhatikan. Kinerja yang baik perlu didukung dengan infrastruktur (sarana dan prasarana), sumber informasi, dan pengetahuan serta keterampilan dari setiap orang dalam perusahaan tersebut. Namun, dengan dorongan inovasi akan lebih meningkatkan kinerja perusahaan. Berdasarkan analisis data yang telah dilakukan, maka peliti menemukan hasil yang positif antara pengetahuan dan keterampilan terhadap kinerja organisasi. Hal ini menunjukkan bahwa semakin tinggi tingkat pengetahuan dan keterampilan dalam setiap orang dalam organisasi akan meningkatkan kinerja organisasi. Sedangkan untuk sumber informasi dan infrastruktur tidak memiliki pengaruh terhadap kinerja organisasi. Pengaruh inovasi dalam memediasi pengetahuan dan keterampilan serta sumber informasi terhadap kinerja perusahaan adalah partial mediasi karena nilai VAF berada pada rentang $>30-<70$. Selain itu inovasi dalam memediasi infrastruktur terhadap kinerja perusahaan adalah full mediasi karena nilai VAF berada pada rentang $>70$. Temuan kami menunjukkan bahwa dengan adanya inovasi tidak memberikan dampak terhadap pengetahuan dan keterampilan serta sumber informasi. Sedangkan inovasi sebagai mediasi memberikan dampak terhadap variabel infrastruktur terhadap kinerja organisasi. Keterbatasan dalam penelitian ini adalah hanya menggunakan 1 perusahaan sebagai sample penelitian, sehingga kurang bisa menggeneralisasi hasil temuan ini. Oleh sebab itu, penelitian selanjutnya dapat menggunakan lebih dari satu perusahaan agar hasil yang diperoleh lebih relevan.

\section{REFERENSI}

Bastian, I. (2001). Akuntansi sektor publik Indonesia. Pusat Pengembangan Akuntansi, Fakultas Ekonomi Universitas Gadjah Mada.

Agbim, K. C., Oriarewo, G. O., \& Omattah, A. E. (2013). An exploratory study of the relationship between innovation and change management. International Journal of Scientific and Research Publications, 3(6), 1-7.

Aldi, B. E. (2005). Menjadikan Manajemen Pengetahuan Sebagai Keunggulan Kompetitif Perusahaan Melalui Strategi Berbasis Pengetahuan. Jurnal Studi Manajemen Dan Organisasi (JSMO), 2(Nomor 1), 58-68.

Avlonitis, G. J., Papastathopoulou, P. G., \& Gounaris, S. P. (2001). An empirically- based typology of product innovativeness for new financial services: Success and failure scenarios. Journal of Product Innovation Management: an international publication of the product development $\mathcal{E}$ 
management association, 18(5), 324-342.

Bontis, N., Crossan, M. M., \& Hulland, J. (2002). Managing an organizational learning system by aligning stocks and flows. Journal of Management Studies, 39(4), 437-469.

Broadbent, M., \& Weill, P. (1997). Management by maxim: how business and IT managers can create IT infrastructures. Sloan Management Review, 38, 77-92.

Brown, A. D., \& Starkey, K. (1994). The effect of organizational culture on communication and information. Journal of Management Studies, 31(6), 807828.

Choy Chong, S., Salleh, K., Noh Syed Ahmad, S., \& Syed Omar Sharifuddin, S.-I. (2011). KM implementation in a public sector accounting organization: an empirical investigation. Journal of Knowledge Management, 15(3), 497-512.

Davenport, T. H. (1998). Putting the enterprise into the enterprise system. Harvard Business Review, 76(4).

Davis, F. D. (1989). Perceived usefulness, perceived ease of use, and user acceptance of information technology. MIS Quarterly, 319-340.

Davis, F. D., Bagozzi, R. P., \& Warshaw, P. R. (1989). User acceptance of computer technology: a comparison of two theoretical models. Management Science, 35(8), 982-1003.

Dessler, G. (1997). Manajemen Sumber daya manusia, PT. Prenhallindo, Jakarta.

Eisenhardt, K. M., \& Martin, J. A. (2000). Dynamic capabilities: what are they? Strategic Management Journal, 21(10- 11), 1105-1121.

Ellitan, L., \& Anatan, L. (2009). Manajemen Inovasi transformasi menuju organisasi kelas dunia. Bandung: Alfabeta.

Galbraith, J. (1973). Designing complex organizations.

Grigg, N., \& Darrel, F. G. (2000). Infrastructure System Management \& Optimization. In Internasional Seminar "Paradigm \& Strategy of Infrastructure Management" Civil Engeenering Departement Dipononegoro University.

Han, J. K., Kim, N., \& Srivastava, R. K. (1998). Market orientation and organizational performance: is innovation a missing link? Journal of Marketing, 62(4), 30-45.

Huang, J., Nam, Y., \& Sherraden, M. S. (2013). Financial knowledge and child development account policy: A test of financial capability. Journal of Consumer Affairs, 47(1), 1-26.

Kusumo, A. R. W. (2006). Analisis Faktor-Faktor Yang Mempengaruhi Inovasi Produk Untuk Meningkatkan Keunggulan Bersaing Dan Kinerja Pemasaran (Studi Pada Industri Batik Skala Besar Dan Sedang Di Kota Dan Kabupaten Pekalongan). program Pascasarjana Universitas Diponegoro.

Laudon, K. C., \& Laudon, J. P. (2015). Management Information Systems: Managing the Digital Firm Plus MyMISLab with Pearson eText--Access Card Package. Prentice Hall Press.

Liebowitz, J. (1999). Knowledge management handbook. CRC press.

Mahsun, M. (2006). Pengukuran kinerja sektor publik. Yogyakarta: BPFE.

Nijssen, S., \& Kok, J. N. (2004). A quickstart in frequent structure mining can make a difference. In Proceedings of the tenth ACM SIGKDD international conference on Knowledge discovery and data mining (pp. 647-652). ACM.

Nongkeng, H. (2012). Pengaruh Pemberdayaan, Komitmen Organisasional 
terhadap Kinerja dan Kepuasan Kerja Dosen (Persepsi Dosen Dipekerjakan PTS Kopertis Wilayah IX Sulawesi di Makassar). Jurnal Aplikasi Manajemen, 10(3), 574-585.

Oktari, R., \& Nasir, A. (2011). Pengaruh Pemanfaatan Teknologi Informasi dan Pengendalian Intern Terhadap Kinerja Instansi Pemerintah (Studi Pada Satuan Kerja Perangkat Daerah Kabupaten Kampar). Jurnal Ekonomi Universitas Riau, 19(2).

Omar Sharifuddin Syed-Ikhsan, S., \& Rowland, F. (2004). Knowledge management in a public organization: a study on the relationship between organizational elements and the performance of knowledge transfer. Journal of Knowledge Management, 8(2), 95-111.

Rachman, A. A. (2014). The Effect of Organization Commitment and Procedural Fairness on Participative Budgeting and Its Implication to Performance Moderating by Management Accounting Information (A Survey on Province Local Government Unit Agencies of West Java). Review of Integrative Business and Economics Research, 3(1), 201.

Rahadi, D. R. (2007). Peranan Teknologi Informasi dalam peningkatan pelayanan di sektor publik. In Seminar Nasional Teknologi.

Schiemann, W. A. (2011). Alignment, capability, engagement. Pendekatan Baru Talent Management Untuk Mendongkrak Kinerja Organisasi.

Schön, D. A., \& Schön, D. A. (1971). Beyond the stable state: Public and private learning in a changing society. Maurice Temple Smith Limited.

Sirait, J. T. (2006). Memahami aspek-aspek pengelolaan sumber daya manusia dalam organisasi. Jakarta: PT Grasindo.

Stacey, G. S., \& Ashton, W. B. (1990). A structured approach to corporate technology strategy. International Journal of Technology Management, 5(4), 389-407.

Stankosky, M. A. (2005). Advances in knowledge management: University research toward an academic discipline. In Creating the discipline of knowledge management (pp. 1-14). Elsevier.

Woodward, D. G., Edwards, P., \& Birkin, F. (1996). Organizational legitimacy and stakeholder information provision 1. British Journal of Management, 7(4), 329347. https://doi.org/https:// doi.org/10.1111/j.1467-8551.1996.tb00123.x 